\title{
Effect of abnormal liver function on vitamin E status and supplementation in adults with cystic fibrosis
}

\author{
R J STEAD, D P R MULLER, SUSAN MATTHEWS, \\ MARGARET E HODSON, AND J C BATTEN \\ From the Brompton Hospital and the Cardiothoracic Institute, Fulham Road and The Institute of Child \\ Health, Guilford Street, London
}

SUMMARY Patients with cystic fibrosis tend to have reduced serum concentrations of vitamin $\mathrm{E}$ and are therefore at risk of developing the neurological complications associated with vitamin $\mathrm{E}$ deficiency. Improved survival in cystic fibrosis has resulted in an increasing number of older patients who may develop hepatobiliary complications which may further impair the absorption of vitamin E. In this study the vitamin E status and results of supplementation with oral vitamin $\mathrm{E}$ were compared in adult patients with and without evidence of liver involvement as assessed by routine liver function tests. The serum vitamin $E$ concentrations were reduced below normal in 24 of 25 patients. The mean serum vitamin $E$ concentration was significantly lower $(p<0 \cdot 05)$ in those patients with abnormal liver function. When vitamin E status was assessed as the serum vitamin E/cholesterol ratio, however, there was no significant difference between those patients with normal and abnormal liver function. After supplementation with oral vitamin $\mathrm{E}$, either $10 \mathrm{mg} / \mathrm{kg} /$ day for one month or $200 \mathrm{mg} /$ day (equivalent to 3.4 to $4.4 \mathrm{mg} / \mathrm{kg} /$ day) for up to three months, there was no significant difference in the vitamin $E$ status between the two groups. The results of this study indicate that in general, patients with cystic fibrosis and abnormal liver function do not require increased supplements of vitamin $E$ compared with those with normal liver function.

A severe deficiency of vitamin E resulting from prolonged fat malabsorption is a recognised cause of a spinocerebellar disorder comprising areflexia, ataxia, and proprioceptive loss. This syndrome has been described in abetalipoproteinaemia ${ }^{1-3}$ and in children with chronic liver disease. ${ }^{4-8}$ It has also been reported in a few cases of adults and children with extensive ileal resection ${ }^{9-10}$ and patients with cystic fibrosis. ${ }^{11-13}$

Reduced serum concentrations of vitamin $E$ have been frequently documented in children and adults with cystic fibrosis ${ }^{14-17}$ but the development of overt neurological disease is, relatively rare. In the patients in whom it has been described there have been complications in addition to pancreatic insufficiency which would be expected to further impair absorption of fat and the fat soluble vitamins such as vitamin E. Thus the two patients reported by Elias $e t$

Address for correspondence: Dr D P R Muller, Department of Child Health, Institute of Child Health, 30 Guilford Street, London WC1N 1EH.

Received for publication 9 September 1985 $a l^{11}$ had a luminal bile salt concentration which was below the critical micellar concentration and hepatomegaly respectively. The other cases in whom clinical details are available had multiple ileal resections ${ }^{12}$ or severe liver disease. ${ }^{13}$ In a study of 29 unselected patients who had no neurological symptoms one patient had definite reflex and sensory abnormalities and another two were abnormal on neurophysiological grounds. ${ }^{13}$ Neurological abnormalities were found in 1.5 and $2.5 \%$ patients in two other series of patients with cystic fibrosis. ${ }^{18} 19$

Adequate luminal bile salt concentrations are necessary for the efficient solubilisation and absorption of such hydrophobic compounds as tocopheryl acetate (vitamin E acetate). ${ }^{20}{ }^{21}$ Patients with cystic fibrosis have an increased faecal loss of bile salts ${ }^{22}$ which can result in a reduced bile salt pool and reduced intraluminal bile salt concentrations. ${ }^{23}$ The prevalence of hepatobiliary disease in cystic fibrosis has increased with improved survival ${ }^{24}$ and in patients with this complication there may be a further reduction in intestinal bile salt concentrations. 
The purpose of this study was therefore to document the effect of abnormal liver function on the vitamin $E$ status and ease of supplementation of adults with cystic fibrosis. This would provide information as to whether patients with abnormal liver function tended to have lower serum concentrations of vitamin $\mathrm{E}$ and whether they might require higher doses of vitamin $E$ supplements to maintain normal serum concentrations.

\section{Methods}

\section{PATIENTS}

Twenty five adult patients with cystic fibrosis (15 men, 10 women) from the Brompton Hospital, London, were studied. All had a sweat sodium concentration greater than $70 \mathrm{mmol} / \mathrm{l}$ and had the typical clinical features of the condition including pancreatic insufficiency. Their mean age was 24.6 years (range 17-41 years).

Liver function was assessed by measurement of serum alkaline phosphatase, aspartate aminotransferase and gamma glutamyl transpeptidase activities. The activities of all these enzymes were consistently normal (measured on at least two occasions) in 16 patients (eight men, eight women) and they were classified as having normal liver function. The other nine patients (seven men, two women) had abnormal liver function tests as defined by activities of alkaline phosphatase which were consistently greater than $250 \mathrm{IU} / \mathrm{l}$ (normal range 50-200 IU/l) and a consistent rise of aspartate aminotransferase (normal range 5-17 IU/l) and/or gamma glutamyl transpeptidase (normal range 5-28 and 3-14 IU/l for men and women respectively). The spleen was palpable, suggesting a degree of portal hypertension, in six of the nine patients with abnormal liver function which suggests a degree of portal hypertension, although none of them had evidence of oesophageal varices. In none of the patients with normal liver function was the spleen palpable. Patients who had only raised alkaline phosphatase or a transient rise in the other enzymes were not included in the study. All the patients were receiving pancreatic enzymes and a multivitamin supplement (which did not contain vitamin E) before and during the course of the study.

In all of the patients, serum vitamin E estimations were carried out before and after supplementation with oral vitamin $E(10 \mathrm{mg} / \mathrm{kg}$ body weight/day) for one month. In some of them a lower dose of vitamin $\mathrm{E}(200 \mathrm{mg} /$ day, equivalent to 3.4 to $4.4 \mathrm{mg} / \mathrm{kg} /$ day $)$ was then evaluated.

Serum vitamin E concentrations were measured colorimetrically ${ }^{25}$ and cholesterol concentrations were estimated enzymatically using a commercial kit supplied by Abbott Laboratories Limited. All the specimens were coded. The code was broken at the end of the first supplementation study. Liver function tests were undertaken by routine methods. Results are expressed, unless stated otherwise, as mean $\pm 1 S D$ and the significance of differences between mean values was calculated by the two tailed Student's $t$ test.

\section{Results}

VITAMIN E STATUS BEFORE SUPPLEMENTATION The mean age of the patients with normal liver function was greater $(\mathrm{p}<0.01)$ than those with abnormal liver function $(28 \cdot 0 \pm 6 \cdot 3$ and $21 \cdot 2 \pm 1 \cdot 9$ years respectively). The serum cholesterol concentrations and vitamin $\mathrm{E}$ status are shown in Figure 1. Only one patient (with normal liver function) had a normal serum vitamin $\mathrm{E}$ concentration (normal range 11.5 to $35.0 \mu \mathrm{mol} / \mathrm{I}^{25}$ ), whereas when vitamin E status was expressed as the serum vitamin E/cholesterol ratio, three patients (all with normal liver function) had normal ratios (greater than $2 \cdot 1 \mu \mathrm{mol} / \mathrm{mmol}$ ). The serum cholesterol concentrations in the two groups were similar; $3.6 \pm 0.9$ and $3 \cdot 2 \pm 0.8 \mathrm{mmol} / \mathrm{l}$ for those with normal and abnormal liver function respectively (normal range being 2.9 to $7 \cdot 8 \mathrm{mmol} / /^{26}$ ). The patients with abnormal liver function had a mean serum vitamin $E$ concentration which was just significantly lower $(p<0.05)$ than that of patients with normal liver function (3.0 1.6 and $6 \cdot 2 \pm 4 \cdot 3 \mu \mathrm{mol} / \mathrm{l}$ respectively). There was, however, no significant difference in the serum vitamin

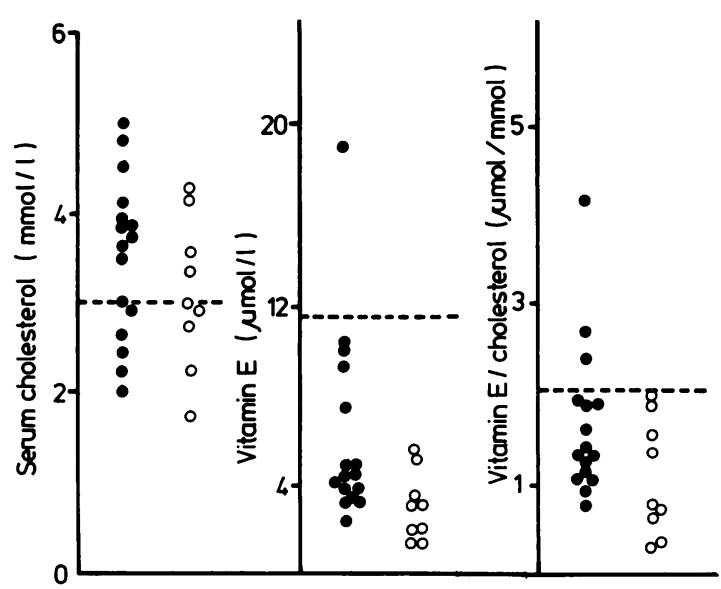

Fig. 1 Serum cholesterol concentrations and vitamin $E$ status of adults with cystic fibrosis. patients with normal liver function, O patients with abnormal liver function, - - -denotes the lower limit of normal. 
$\mathrm{E} /$ cholesterol ratios $(1.1 \pm 0.6$ and $1.7 \pm 0.9 \mu \mathrm{mol} / \mathrm{mmol}$ for those with abnormal and normal liver function respectively).

\section{VITAMIN E CONCENTRATIONS AFTER} SUPPLEMENTATION

Tocopheryl acetate $10 \mathrm{mg} / \mathrm{kg} /$ day

Fifteen patients (eight with normal and seven with abnormal liver function) were given vitamin $\mathrm{E}$ in the form of DL alpha tocopheryl acetate (Ephynal-Hoffmann La Roche \& Co) at a dose of $10 \mathrm{mg} / \mathrm{kg} /$ day for one month. The increase in serum vitamin $E$ concentrations and vitamin $E / c h o l-$ esterol ratios over time are shown in Figure 2. There were no significant differences between the two groups in the mean rise of the serum vitamin $E$ concentrations $(15 \cdot 2 \pm 7 \cdot 2$ and $12 \cdot 6 \pm 7 \cdot 3 \mu \mathrm{mol} / \mathrm{l})$ or in the mean rise in the vitamin E/cholesterol ratios $(4.5 \pm 1.9$ and $4.5 \pm 2.5 \mu \mathrm{mol} / \mathrm{mmol})$ in the patients with normal and abnormal liver function respectively).

In all except three patients (one with normal and two with abnormal liver function) the serum vitamin $E$ concentrations reached the normal range within one month. These three patients were treated for longer with $10 \mathrm{mg} / \mathrm{kg} /$ day of vitamin $E$ and they all had normal serum concentrations of vitamin $E$ after a further four to six months of supplementation (9.7 increasing to $18.1,3.5$ to 12.2 , and 9.1 to $13.4 \mu \mathrm{mol} / \mathrm{l}$ ). Only one of these patients (who had abnormal liver function), had a vitamin $\mathrm{E} /$ cholesterol ratio below normal $(0.8 \mu \mathrm{mol} / \mathrm{mmol})$ and this rose to within the normal range $(2.8 \mu \mathrm{mol} /$ mmol) after a further six months of treatment.

Tocopheryl acetate $200 \mathrm{mg} /$ day

After the trial of $10 \mathrm{mg} / \mathrm{kg} /$ day of vitamin E, eight of
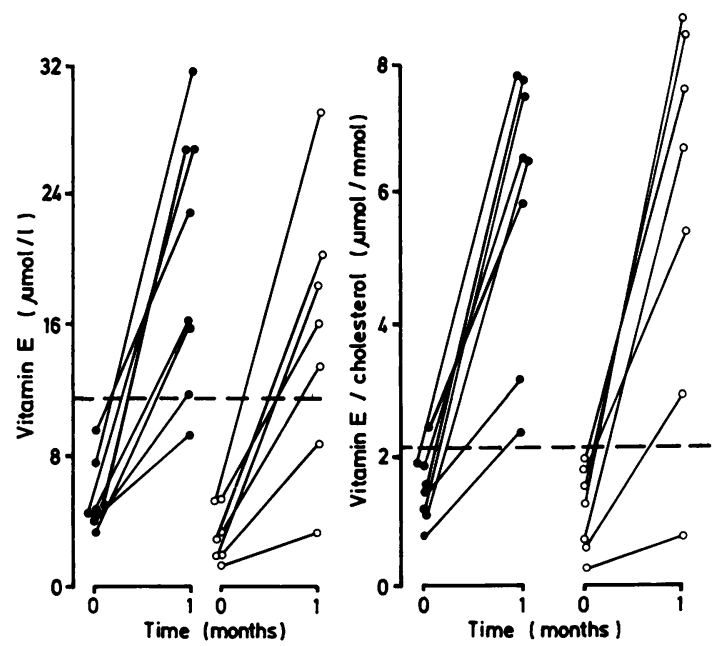

Fig. 2 Vitamin E status after supplementation with tocopheryl acetate $(10 \mathrm{mg} / \mathrm{kg} /$ day $) \longrightarrow$ patients with normal liver function, $\mathrm{O}-\mathrm{O}$ patients with abnormal liver function, - - -denotes the lower limit of normal.

the patients were requested to continue on this dose but compliance was erratic. After an interval of one to seven months serum vitamin $\mathrm{E}$ concentrations were again measured and the patients were then instructed to take just one tablet of tocopheryl acetate daily $(200 \mathrm{mg} /$ day equivalent to $3 \cdot 4-4 \cdot 4$ $\mathrm{mg} / \mathrm{kg} / \mathrm{day}$ ) and concentrations of the vitamin were measured after a further one to three months. Details of the vitamin $E$ intake between the two trials and the serum vitamin $\mathrm{E}$ concentrations before and after the reduced dose of $200 \mathrm{mg} /$ day are shown in the Table. In patients 1 and 5 serum vitamin $E$

Table Details and vitamin $E$ status of patients given $200 \mathrm{mg} /$ day tocopheryl acetate

\begin{tabular}{|c|c|c|c|c|c|c|c|c|}
\hline \multirow[b]{4}{*}{ Patient } & \multirow{4}{*}{$\begin{array}{l}\text { Liver } \\
\text { function }\end{array}$} & \multirow{2}{*}{\multicolumn{2}{|c|}{ Vitamin $E-10 \mathrm{mg} / \mathrm{kg} /$ day }} & \multicolumn{2}{|c|}{$\begin{array}{l}\text { Period between } \\
2 \text { supplements }\end{array}$} & \multicolumn{3}{|c|}{ Vitamin $E-200 \mathrm{mg} /$ day } \\
\hline & & & & & \multirow{3}{*}{$\begin{array}{l}\text { Claimed } \\
\text { vit } E \text { intake } \\
m g / k g / d a y\end{array}$} & \multirow{2}{*}{\multicolumn{2}{|c|}{$\begin{array}{l}\text { Vitamin } E \text { conc } \\
(\mu \mathrm{mol} / \mathrm{l})\end{array}$}} & \multirow{3}{*}{$\begin{array}{l}\text { Time on } \\
\text { supplement }(\mathrm{mn})\end{array}$} \\
\hline & & Vitamin & $E$ conc (umollu) & \multirow{2}{*}{$\begin{array}{l}\text { Time } \\
(m n)\end{array}$} & & & & \\
\hline & & Start & after 1 month & & & Start & End & \\
\hline 1 & Normal & $4 \cdot 5^{*}$ & $27 \cdot 1$ & 6 & 10 & $39 \cdot 6$ & $28 \cdot 8$ & 3 \\
\hline 3 & Normal & $3 \cdot 3$ & $16 \cdot 2$ & 5 & 9 & $11 \cdot 4$ & $15 \cdot 3$ & 1 \\
\hline 4 & Normal & $4 \cdot 6$ & $16 \cdot 4$ & 4 & 8 & $17 \cdot 5$ & $15 \cdot 1$ & 2 \\
\hline 5 & Abnormal & $5 \cdot 3$ & $29 \cdot 4$ & 1 & 10 & $38 \cdot 4$ & $25 \cdot 7$ & 2 \\
\hline 6 & Abnormal & $3 \cdot 1$ & $20 \cdot 5$ & 7 & $4 \ddagger$ & $9 \cdot 2$ & $12 \cdot 2$ & 1 \\
\hline 7 & Abnormal & $5 \cdot 6$ & $16 \cdot 4$ & 5 & 7 & $12 \cdot 2$ & 12.9 & 1 \\
\hline 8 & Abnormal & $1 \cdot 4$ & $3 \cdot 5$ & 3 & 10 & $12 \cdot 2$ & $6 \cdot 1$ & 3 \\
\hline
\end{tabular}

*Normal range 11.5 to $35.0 \mu \mathrm{mol} / \mathrm{l}$.

$\nmid$ Did not take any vitamin $E$ for one week immediately before start of second supplement $(200 \mathrm{mg} /$ day $)$.

$\ddagger$ Took an increased dose (approx. $11 \mathrm{mg} / \mathrm{kg} /$ day) immediately before start of second supplement $(200 \mathrm{mg} / \mathrm{day})$. 
concentrations decreased from supranormal to normal. They had maintained their large dose of vitamin $\mathrm{E}(10 \mathrm{mg} / \mathrm{kg} / \mathrm{day})$ between the two study periods. In the other patients, with the exception of patient 8, serum vitamin $E$ concentrations tended to rise from a starting level which was around the lower limit of normal. Patient 8 whose serum concentration of vitamin $E$ fell from 12.2 to $6 \cdot 1 \mu \mathrm{mol} / \mathrm{l}$ after three months on the lower dose of the vitamin had the highest activities of alkaline phosphatase and aspartate transaminase recorded in this study (2900 and 83 IU/l respectively). With this one exception there was no difference in response between those patients with normal and abnormal liver function.

\section{Discussion}

The purpose of this study was to determine whether adult patients with cystic fibrosis and evidence of abnormal liver function differed in their vitamin $\mathrm{E}$ status and response to supplements of the vitamin compared with similar patients with normal liver function. There has recently been discussion in the literature as to the best way of defining vitamin $E$ deficiency. It has been suggested that serum vitamin E concentrations should be expressed per total lipid or cholesterol concentrations. ${ }^{27-29}$ In conditions such as cholestatic liver disease serum lipid concentrations tend to be increased and thus a patient with an apparently normal serum vitamin E concentration may have a reduced vitamin E/lipid ratio and possible vitamin $\mathrm{E}$ deficiency. ${ }^{2 y}$ In our patients, however, serum cholesterol concentrations tended to be reduced and therefore the opposite - that is, a normal ratio with a reduced serum vitamin $E$ concentration, might be expected.

In this study vitamin $E$ status was assessed by serum vitamin $E$ concentrations and the serum vitamin $\mathrm{E} /$ cholesterol ratio. Using both these indices the majority of patients had vitamin E deficiency. This is in agreement with a number of previous studies in both children and adults ${ }^{14-17}$ with cystic fibrosis. Of the 25 patients studied, only one had a normal serum vitamin $E$ concentration whereas in three the vitamin E/cholesterol ratio was normal.

When the patients were divided according to their liver function tests, the mean serum vitamin $E$ concentration in the patients with abnormal liver function was just significantly lower $(p<0 \cdot 05)$ than that of patients with normal liver function. A corresponding difference was not, however, apparent when the mean vitamin E/cholesterol ratios were compared.

In an earlier study in children with cystic fibrosis ${ }^{16}$ we reported that normal serum concentrations of vitamin $E$ could be achieved within one month on a dose of $10 \mathrm{mg} / \mathrm{kg} /$ day of the fat soluble preparation of the vitamin. The same dose was therefore, used for a similar period in this study. The majority of the patients (12 out of 15) achieved normal serum concentrations after one month and only one failed to achieve a normal vitamin E/cholesterol ratio. There were no significant differences after supplementation in the mean serum concentrations and ratios between the patients with normal and abnormal liver function. After this dose of $10 \mathrm{mg} / \mathrm{kg} / \mathrm{day}$ and a period of variable vitamin $E$ intake we observed that a normal vitamin $E$ status could be maintained in all except one patient with a dose of $200 \mathrm{mg} /$ day (equivalent to $3.4-4.4 \mathrm{mg} / \mathrm{kg} /$ day). The exception was the patient with the highest activities of alkaline phosphatase and aspartate aminotransferase.

Because of the relationship between severe vitamin E deficiency and neurological dysfunction ${ }^{1}$ and in view of the uncertainty about the degree of vitamin E deficiency required to cause neurological dysfunction, it seems prudent to suggest that where possible serum vitamin $\mathrm{E}$ status should be measured in all patients with cystic fibrosis and maintained within normal limits by appropriate supplementation. If it is not possible to regularly monitor serum vitamin $E$ concentrations we would suggest an initial dose of $10 \mathrm{mg} / \mathrm{kg} / \mathrm{day}$ for at least one month followed by a maintenance dose of $200 \mathrm{mg} / \mathrm{day}$ - for example one tablet of Ephynal. This dosage schedule appears to be adequate for all adult patients with the exception of those with grossly abnormal liver function tests. In these latter patients, we would strongly advise that serum vitamin E concentrations are regularly estimated and that the dosage of vitamin $\mathrm{E}$ is adjusted accordingly.

Such a policy of supplementing deficient patients would be more practical than carrying out regular detailed neurological assessments and starting treatment only when neurological dysfunction becomes clinically evident. It would have the important advantage of preventing neurological disability which may become more prevalent as the population of patients with cystic fibrosis grows older as a result of improved medical management.

RJS was supported by the Frances and Augustus Newman Foundation and DPRM thanks Hoffmann La Roche and Co for their continuing support.

\section{References}

1 Muller DPR, Lloyd JK, Wolff OH. Vitamin E and neurological function. Lancet 1983; 1: 225-8.

2 Muller DPR, Lloyd JK, Bird AC. Long-term management of abetalipoproteinaemia. Possible role for vitamin E. Arch Dis Childh 1977; 52: 209-14. 
3 Muller DPR, Lloyd JK. Effect of large oral doses of vitamin $\mathrm{E}$ on the neurological sequelae of patients with abetalipoproteinaemia. Ann N Y Acad Sci 1982; 393: 133-44.

4 Rosenblum JL, Keating JP, Prensky AL, Nelson JS. A progressive neurologic syndrome in children with chronic liver disease. $N$ Engl J Med 1981; 304: 503-8.

5 Guggenheim MA, Ringel SP, Silverman A, Grabert $\mathrm{BE}$. Progressive neuromuscular disease in children with chronic cholestasis and vitamin E deficiency: diagnosis and treatment with alpha tocopherol. J Pediatr 1982; 100: $51-8$.

6 Guggenheim MA, Jackson V, Lilly J, Silverman A. Vitamin E deficiency and neurologic disease in children with cholestasis: a prospective study. J Pediatr 1983; 102: 577-9.

7 Alvarez F, Landrieu P, Laget P, Lemonnier F, Odievre $M$, Alagille D. Nervous and ocular disorders in children with cholestasis and vitamin $\mathrm{A}$ and $\mathrm{E}$ deficiencies. Hepatology 1983; 3: 410-4.

8 Sokol RJ, Bove KE, Heubi JE, Iannaccone SI . Vitamin E deficiency during chronic childhood, cholestasis: Presence of sural nerve lesion prior to iwo and a half years of age. J Pediatr 1983; 103: 197-204.

9 Harding AE, Muller DPR, Thomas PK, Willison HJ. Spinocerebellar degeneration secondary to chronic intestinal malabsorption: a vitamin $\mathrm{E}$ deficiency syndrome. Ann Neurol 1982; 12: 419-24.

10 Howard L, Oveson L, Satya-Murti, Chu R. Reversible neurological symptoms caused by vitamin $\mathrm{E}$ deficiency in a patient with short bowel syndrome. Am J Clin Nutr 1982; 36: 1243-9.

11 Elias E, Muller DPR, Scott J. Spinocerebellar disorders in association with cystic fibrosis or chronic childhood cholestasis and virtually undetectable serum concentrations of vitamin E. Lancet 1981; 2: 1319-21.

12 Bye AME, Muller DPR, Wilson J, Wright VM, Mearns MB. Symptomatic vitamin E deficiency in a patient of 10 years with cystic fibrosis. Arch Dis Childh 1984; 60: 162-64.

13 Willison HJ, Muller DPR, Matthews S, et al. A study of the relationship between neurological function and serum vitamin E concentrations in patients with cystic fibrosis. J Neurol Neurosurg Psychiatry 1985; 48: 1097-102.

14 Bennett M, Medwadowski B. Vitamin A, vitamin E and lipids in serum in children with cystic fibrosis or congenital heart defects compared with normal children. Am J Clin Nutr 1967; 20: 415-21.

15 Underwood B, Denning C. Blood and liver concentrations of vitamins $A$ and $E$ in children with cystic fibrosis of the pancreas. Pediatr Res 1972; 6: 26-31.
16 Harries JT, Muller DPR. Absorption of different doses of fat soluble and water miscible preparations of vitamin $\mathrm{E}$ in children with cystic fibrosis. Arch Dis Childh 1971; 46: 341-4.

17 Farrell P M, Bieri JG, Fratantoni JF, Wood RE, di Sant'Agnese PA. The occurrence and effects of human vitamin $\mathrm{E}$ deficiency. A study in patients with cystic fibrosis. J Clin Invest 1977; 60: 233-41.

18 Shwachman H, Kowalski M, Khaw KT. Cystic fibrosis; a new outlook: 70 patients above 25 years of age. Med (Balt) 1978; 56: 129-49.

19 Chabria S, Tomasi LG, Lloyd-Still JD. Neurological manifestations of cystic fibrosis: Lack of relationship to vitamin E deficiency. [Abstract]. Ann Neurol 1978; 4: 194.

20 Harries JT, Muller DPR. Absorption of vitamin E in children with biliary obstruction. Gut 1971; 12: 579-84.

21 Sokol RJ, Heubi JE, Iannaccone S, Bove KE, Balistreri WF. Mechanism causing vitamin E deficiency during chronic childhood cholestasis. Gastroenterology 1983; 85: 1172-82.

22 Weber AM, Roy CC, Morin CL, Lasalle R. Malabsorption of bile acids in children with cystic fibrosis. $N$ Engl J Med 1973; 289: 1001-5.

23 Watkins JB, Tercyak AM, Szczepanik P, Klein PD. Bile salt kinetics in cystic fibrosis: Influence of pancreatic enzyme replacement. Gastroenterology 1977; 73: 1023-8.

24 Park RW, Grand RJ. Gastrointestinal manifestations of cystic fibrosis: A review. Gastroenterology 1981; 81: 1143-61.

25 Muller DPR, Harries JT, Lloyd JK. The relative importance of the factors involved in the absorption of vitamin $\mathrm{E}$ in children. Gut 1974; 15: 966-71.

26 Schaefer EJ, Levy RI. Pathogenesis and management of lipoprotein disorders. $N$ Engl J Med 1985; 312: 1300-10.

27 Horvitt MK, Harvey CC, Dahm CH Jr, Searcy MT. Relationship between tocopherol and serum lipid levels for determination of nutritional adequacy. Ann NY Acad Sci 1971; 203: 223-36.

28 Farrell PM, Levine SL, Murphy MD, Adam AJ. Plasma tocopherol levels and tocopherol-lipid relationships in a normal population of children as compared to healthy adults. Am J Clin Nutr 1978; 31: 1720-6.

29 Sokol RJ, Heubi JE, Iannaccone ST, Bove KE, Balistreri WF. Vitamin E deficiency with normal serum vitamin $\mathrm{E}$ concentrations in children with chronic cholestasis. N Engl J Med 1984; 310: 1209-12. 